\title{
Penggunaan Data Penginderaan Jauh dan Sistem Informasi Geografis untuk Pembuatan Prototipe Perangkat Lunak Simulasi Penyebaran Kebakaran Hutan
}

\author{
Agung Mulyo Widodo ${ }^{1,}$ Dulbahri' ${ }^{2}$ dan Hartono ${ }^{3}$ \\ Fakultas Ilmu Komputer, Universitas Esa Unggul Indonesia ${ }^{1}$ dan Fakultas Geografi Universitas Gadjah Mada, \\ Indonesia ${ }^{2,3}$ \\ Email Koresponden:agungmulyowidodo@gmail.com
}

Diterima: 11 Oktober 2016 /Disetujui:30 Januari 2017/ Publikasi online: 31 Maret 2017 (c) 2017 Fakultas Geografi UGM dan Ikatan Geograf Indonesia (IGI)

\begin{abstract}
Abstrak Telah didesain dan disusun prototipe perangkat lunak model interaktif kebakaran hutan, yang dapat memberikan skenario terjadinya kebakaran hutan dengan masukan berupa lokasi titik api (hotspot) dan keluaran berupa informasi lokasi penyebaran kebakaran, luas kebakaran, waktu simulasi yang diperlukan untuk mencapai luas kebakaran serta kecepatan penyebaran kebakaran. Prototipe model interaktif ini dibangun dengan mendefinisikan suatu satuan perluasan eskalasi kebakaran (FirePixel) yang mewakili granularitas data riil lapangan sebesar 400X400 m, letak (posisi geografis) dan luasan pengamatan simulasi kebakaran yang dapat dikustomisasi (disetting) oleh pengguna secara interaktif dengan asumsi kondisi pada sebuah satuan perluasan eskalasi kebakaran atau Fire Pixel diasumsikan homogen dengan parameter konfigurasi vegetasi, kelerengan, sebaran gambut, sebaran batubara sebagai faktor internal dan faktor eksternal yaitu faktor tetangga terdekat, kecepatan dan arah angin, temperatur rata-rata, kelembaban rata-rata dari simulasi dapat dikustomisasi secara interaktif pada saat simulasi. Dalam perhitungan proses kebakaran dan proses pemadaman kebakaran hutan didefinisikan faktor percepatan proses kebakaran yang merupakan akumulasi dari faktor internal dan eksternal yang secara langsung mempengaruhi kecepatan terjadinya proses kebakaran dan pemadaman kebakaran hutan. Perubahan fase kebakaran diperoleh melalui pemodelan matematik dari faktor internal dan eskternal mulai dari fase mulai terbakar sampai kebakaran padam. Hasil validasi prototipe diperoleh kebenaran yang dapat diterima dalam perhitungan statistik menggunakan Uji Kolmogorov-Smirnov Dua Sampel. Hasil skenario 1 menghasilkan nilai KD hitung $(=1,5722)<$ KD tabel $(-1,9176)$ dan skenario 2 menghasilkan nilai KD hitung $(=1,36)<$ nilai KD tabel $(=1,5722)$.
\end{abstract}

Kata kunci: model interaktif, satuan ekskalasi kebakaran, faktor internal kebakaran, faktor eksternal kebakaran, faktor percepatan proses kebakaran

\begin{abstract}
It has been designed and structured software prototype interactive model of forest fires, which can provide forest fire scenario, input is the location of hotspots and the output of the location information spread of fire, extensive fires, the simulation time required to reach the area of the fires and speed of fire deployment. The prototype interactive model is built by defining an expansion unit escalation fire (FirePixel) that represent real data granularity field of $400 \times 400 \mathrm{~m}$, position (geographical) and the extent of the fire simulation observations that can be customized (be set) by the user interactively by assuming the conditions in a expansion unit escalation of fire or fire pixel assumed homogeneous with the parameters: configuration of vegetation, slope, the distribution of peat, coal distribution as internal factors and external factors that factor nearest neighbors, wind speed and direction, average temperature, average humidity of the simulation can be customized interactively during the simulation. In the calculation of the fire and the fire fighting forest, fires the acceleration factor is defined as an accumulation of internal and external factors that directly affect the speed of the process of extinguishing fires and forest fires. Fire phase change obtained through mathematical modeling of internal and external factors ranging from phase start to burn until the fire goes out. Prototype validation results obtained acceptable truth in statistical calculations using the Kolmogorov Smirnov Two Sample. Results 1 scenario produces KDcount value $(=1.5722)<$ KD table value $(-1.9176)$ and scenario 2 yields the KDcount value $(=1.36)<$ KDtable value $(=1.5722)$.
\end{abstract}

Keywords: interactive model, unit of escalation fire, fire internal factors, fire external factors, fire acceleration factor

\section{PENDAHULUAN}

Akibat kebakaran hutan yang sangat merugikan, mendorong peneliti untuk mendesain dan menyusun suatu model perangkat lunak/aplikasi yang mampu mensimulasikan terjadinya kebakaran hutan dengan keluaran berupa informasi lokasi penyebaran kebakaran, luas kebakaran, waktu yang diperlukan untuk mencapai luas kebakaran serta kecepatan penyebaran kebakaran, sehingga dapat dirumuskan permasalahan yaitu:

1.Bagaimana menyusun suatu sistem simulasi kebakaran hutan ini, yang dapat dioperasikan secara interaktif oleh pengguna dengan berbagai faktor yang terlibat dan berpengaruh terhadap kondisi kebakaran 
tersebut.

2.Apakah sistem simulasi kebakaran hutan yang disusun ini mampu merepresentasikan kondisi riil dilapangan (real world).

Tujuan dari penelitian ini adalah ;1). tersusunnya suatu prototipe aplikasi perangkat lunak yang secara interaktif mampu mengimple-mentasikan terjadinya simulasi pola kebakaran hutan hutan berdasarkan faktor-faktor internal yang berupa konfigurasi vegetasi, kemiringan lereng, sebaran batubara, sebaran gambut serta faktor-faktor eksternal yang berupa faktor jarak tetangga terdekat dan faktor lingkungan yang berupa temperatur, kelembaban, arah dan kecepatan angin, 2). melakukan uji prototipe aplikasi perangkat lunak dengan masukan berupa data titik api-titik api (hotspot) dari NOAA AVHRR untuk menentukan keakuratan prototype dengan menggunakan analisis statistic.

Kebakaran hutan di Indonesia banyak terjadi sebagai akibat adanya akumulasi bahan bakar (seresah dan sisa tebangan yang kering) yang terdapat di dalam maupun kawasan hutan (Sulthoni, 1985) yang di picu oleh pemanfaatan api oleh manusia merupakan sumber penyebab utama kebakaran hutan. Namun demikian api yang digunakan oleh manusia ini tidak akan menyebabkan kebakaran hutan bila tidak didukung oleh faktor-faktor iklim (kelembaban udara relatif dan kecepatan angin), topografi dan bahan bakar. Topografi kawasan yang miring dan lebih-lebih dibantu angin yang kencang, akan menyebabkan api akan membakar lebih cepat.

Tutupan lahan mencakup informasi vegetasi, yang dalam konteks ini vegetasi yang mempunyai pengaruh langsung pada keseluruhan proses kebakaran hutan seperti pertukaran massa dan energi antara permukaan dan atmosfir.

Gambut mempunyai kedalaman 0 meter dari permukaan tanah hingga beberapa meter dibawah permukaan tanah. Oleh karena itu, apabila lahan ini terbakar, maka api akan merambat melalui bawah permukaan tanah. Kebakaran di bagian lapisan gambut akan dapat muncul api ke arah permukaan sehingga terjadi kebakaran di daerah permukaan tanah.

Kemiringan lereng berhubungan dengan kecepatan pembakaran. Kecepatan angin sangat mempengaruhi kecepatan pembakaran pada berbagai kondisi kemiringan lereng ataupun berbagai kondisi topografi. Dalam kondisi cuaca yang sama, kecepatan pembakaran pada lereng $20 \%$ - 39\% dua kali lebih cepat dibandingkan kecepatan pembakaran pada medan datar (Southwest Interagency Fire Council 1968, dalam Wright and Bailey 1982, dalam Habib Subagio, 2000).

Pada berbagai litologi, kebakaran hutan menjadi semakin parah karena adanya sebaran dan sisipan batubara (Habib Subagio, 2000). Hal ini akan menyebabkan kondisi kering pada lapisan top soil maupun sub soil sebagai akibat kebakaran bahkan akan menimbulkan api abadi apabila ada singkapan batubara langsung ke permukaan tanah sebagai akibat kontak langsung dengan oksigen. Keadaan ini menyebabkan kebakaran apabila disekilingnya berupa bahan bakar kering dan adanya angin

Deteksi kebakaran hutan dapat dilakukan dengan bantuan data penginderaan jauh melalui pengolahan data dengan algoritma tertentu bisa diketahui besar suhu permukaan darat sehingga dari citra sensor satelit penginderaan jauh dapat disadap infromasi tentang sebaran titik-titik api (hotspot) yang merepresentasikan adanya kebakaran hutan pada suatu area.

Dalam melakukan pengembangan sebuah model perangkat lunak yang akan mensimulasikan proses kebakaran hutan memerlukan pemahaman yang komprehensip tentang proses kebakaran hutan tersebut, yang meliputi fase-fase kebakaran hutan, material yang terbakar, faktor-faktor pemicu secara langsung dan faktor lain yang bersifat tidak langsung untuk menurunkan sebuah model matematik yang mampu merepresentasikan setiap fase, proses dan faktor yang terlibat dalam peristiwa kebakaran hutan secara akurat.

Didefinisikan Satuan Perluasan Eskalasi Kebakaran atau disebut Fire Pixel (FP). Sebuah Fire Pixel menunjukkan informasi-informasi pada lokal area (400x400 meter) yang berhubungan dengan fase area, informasi tingkat kemudahan terbakar dan informasi lain yang diperlukan dalam perhitungan, seperti yang ditunjukkan oleh gambar 1, sehingga secara matematis, peta dikonversikan dalam bentuk matriks dengan FP sebagai satuan terkecil informasi (elemen matriks ).

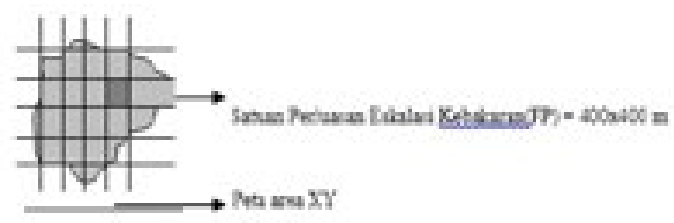

Gambar 1. Satuan Perluasan Eskalasi

\section{Kebakaran (FP)}

Dengan pemodelan secara matriks, proses kebakaran dalam suatu area dapat dihitung secara lokal disekitar area tersebut tanpa melibatkan informasi dalam keseluruhan peta. Semua piksel dalam area pengamatan tersebut mempunyai kondisi awal normal yang menunjukkan belum terjadi kebakaran. Kebakaran hutan diawali dari titik-titik sumber api (fire point) yang ditentukan dalam area observasi. Penambahan titik api tersebut akan menyulut piksel tetangganya (disekitar titik api) mulai terbakar. Akumulasi dari faktor eksternal dan internal yang merupakan komponen dari faktor percepatan, secara langsung akan mempengaruhi kecepatan dan arah penyebaran proses kebakaran dan pemadaman. Besarnya pengaruh dan hubungan antar faktor-faktor tersebut dalam proses kebakaran hutan diturunkan dalam sebuah model matematik yang merepresentasikan proses penyebaran kebakaran hutan dengan semua kemungkinan faktor yang terlibat. 


\section{Faktor Pemicu Kebakaran}

Proses kebakaran dalam tiap satuan FP melibatkan dua faktor utama yang bersifat faktor internal dan faktor eksternal.

Faktor internal berhubungan dengan materimateri dan kondisi dalam sebuah satuan area FP.

Faktor Eksternal merupakan faktor dari luar yang memicu sebuah area FP untuk mulai terbakar. Sebuah area FP yang akan naik tingkat resiko terbakarnya, bila tetangga sekitar pixel tersebut dalam kondisi yang memberikan magnituda pengaruh terbakar yang signifikan. Faktor alam yang memicu proses kebakaran antara lain adalah kecepatan angin, arah angin, temperatur dan kelembaban.

\section{Fase-fase Kebakaran Hutan}

Fase kebakaran hutan terhadap sebuah FP dapat digambarkan secara sederhana seperti Gambar 2.

Fase tersebut terjadi dalam tiap FP bervariasi tergantung pada tingkat resiko kebakaran dan merupakan fungsi waktu, yang bergerak dari fase belum terbakar (A), mulai terbakar (B), terbakar penuh (C), mulai padam (D), sampai padam (E). Fase A (belum terbakar) dan fase $\mathrm{E}$ ( padam) merupakan kondisi tak terhingga $(\sim)$ sehingga tidak diperhitungkan simulasinya. Dalam perpindahan antara tiap fase dikenal Fungsi Inisiator (I) yang menunjukkan tingkatan yang diperlukan sebuah FP untuk pindah dari satu fase ke fase berikutnya, sehingga IAB menunjukkan besar tingkatan (nilai ambang) yang harus dicapai supaya sebuah FP mulai terbakar. Artinya sebuah Initiator dari tiap fase mengacu pada sebuah nilai ambang atau Threshold ( $\mathrm{T}$ ) yang didefinisikan sebagai batas ambang minimum supaya terjadi perpindahan fase proses ke proses selanjutnya. Proses migrasi fase yang terjadi dalam sebuah FP juga dipengaruhi oleh fase yang terjadi pada FP tetangga dan juga mempengaruhi migrasi fase FP tetangga sehingga fungsi Inisiator (I) dan nilai ambang batas (T) dari sebuah FP merupakan perkalian dari faktor-faktor internal yang mengacu pada material dalam FP dan faktor eksternal yang mengacu pada FP tetangga dan faktor-faktor dinamis (temperatur, kelembaban, kecepatan angin dan arah angin), dirumuskan sebagai :

$$
\mathrm{TI}=\underset{(\text { tetangga })}{\text { Eksternal }} \text { (dirinya) }
$$

\section{Fungsi Eksternal}

Fungsi Eksternal merupakan faktor dari luar yang memicu sebuah area FP untuk mulai terbakar. Faktor ini dinyatakan dalam fungsi yang menunjukkan perubahan fase dari suatu FP yang mengalami pengaruh dari tetangganya yang berada dalam fase terbakar atau mulai terbakar. Akibat pengaruh tersebut, meningkatkan nilai inisiasi dari FP tersebut, dan akhirnya berubah fase setelah melewati nilai ambang (T). Faktor tetangga diperhitungkan dinyatakan dalam matriks ganjil, misal $3 \times 3$ yang berarti ada 8 tetanggga sekitar, 5 x 5 dengan 24 tetangga dan seterusnya. Pendefinisian matriks faktor tetangga menentukan tingkat ketelitian perhitungan dan ketepatan simulator. Disamping dipicu oleh faktor yang berhubungan dengan tetangga, perubahan fase kebakaran pada sebuah FP dipengaruhi oleh faktor-faktor alam. Fungsi eksternal dinyatakan sebagai,

$$
\stackrel{2}{\sum}\left(\mathrm{FP}_{\text {tetangga }} \mathrm{x}\right. \text { Faktor Iklim). }
$$

Fungsi Afektifitas (Af) didefinisikan sebagai kemampuan menulari tetangga di sekitarnya untuk mulai terbakar yang berkaitan dengan tingkat energi yang dilepaskan. Sehingga fungsi eksternal dirumuskan sebagai

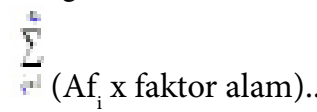

ditentukan faktor Afektivitas (Af) yang berpengaruh adalah, bahan bakaran (bb) (konfigurasi vegetasi) dan kondisi/ state lahan (sl)
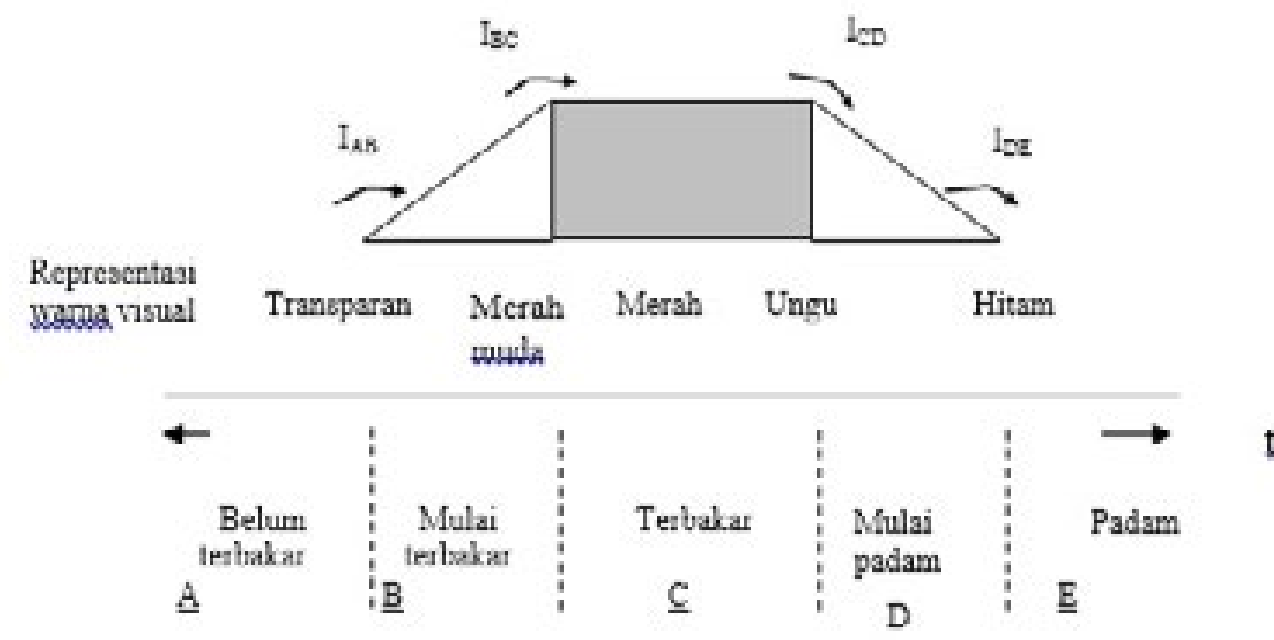

Gambar 2. Fase-fase kebakaran hutan 


\section{Magnitude Korelatif (mk)}

Didefinisikan magnituda korelatif sebagai besarnya andil suatu faktor yang dapat dalam mengakibatkan terjadinya peristiwa kebakaran. Masing-masing faktor afektivitas di atas mempunyai nilai magnitude korelatif (mk) dan nilai Indeks intensitas (I) sehingga,

Faktor Afektivitas $(\mathrm{Af})=\left(\left(\mathrm{mk}_{\mathrm{bb}} \times \mathrm{I}_{\mathrm{bb}}\right)+\left(\mathrm{mk}_{\mathrm{sl}} \times \mathrm{I}_{\mathrm{sl}}\right)\right) \ldots(4)$

Dalam hal ini ditentukan, jumlah total magnituda korelatif dari seluruh korelator faktor afektivitas adalah $=1$. Intensitas dari masing-masing faktor afektivitas adalah index $0 \leq \mathrm{I} \leq 1$. Sehingga nilai faktor afektivitas (Af) maksimum adalah 1 yang menunjukkan bahwa FP bersangkutan mampu secara penuh menginisiasi tetangganya untuk mulai terbakar.

\section{Faktor Alam}

Faktor yang berpengaruh secara langsung pada FP adalah kecepatan angin $\left(\mathrm{W}_{\mathrm{v}}\right)$, arah angin $(\mathrm{Wa})=$ adalah komponen Cos $\alpha$ dari besar sudut garis normal dengan arah angin. ( garis normal = garis yang menghubungkan titik pusat FP yang dihitung dengan titik pusat FP sebuah tetangga bersangkutan ). Berlaku hanya jika -90 $\leq \alpha \leq 90$, selain nilai $\alpha$ tersebut, komponen $\mathrm{W} \alpha=0$ dan jarak dengan tetangga $\left(\mathrm{N}_{\mathrm{d}}\right)$, didefinisikan sebagai index 1 untuk bertetangga langsung, 0.5 terpisah oleh 1 FP, 0.25 terpisah oleh 2 FP. Faktor alam dapat dirumuskan.

Faktor alam $=\mathrm{W}_{\mathrm{v}} \times \mathrm{Wa} \times \mathrm{N}_{\mathrm{d}}$

dari rumus (4) dan (5) maka Faktor Eksternal menjadi,(6)

Fungsi eksternal $=\dot{\Sigma}\left[\left(\left(\mathrm{mk}_{\mathrm{bb}} \mathrm{xI}_{\mathrm{bb}}\right)+\left(\mathrm{mk}_{\mathrm{sl}} \mathrm{xI}_{\mathrm{sl}}\right)\right) \mathrm{xW}_{\mathrm{v}}\right.$ $\mathrm{x} \operatorname{Wax} \mathrm{N}_{\mathrm{d}}$ ]. ..(6)

\section{Fungsi Internal}

Faktor internal berhubungan dengan materi-materi dalam sebuah satuan area FP, sehingga sebuah area FP memiliki resiko terbakar lebih besar, sama atau lebih kecil dari area FP lain. Didefinisikan faktor yang menunjukkan tingkat resiko suatu FP adalah : bahan bakaran (bb) / (konfigurasi vegetasi), temperatur (t), humidity/kelembapan (h).

Fungsi internal $=\left(\left(m_{b b} \mathrm{I}_{b b}\right)+\left(m_{t} \mathrm{xI}_{\mathrm{t}}\right)+\left(\mathrm{mk}_{\mathrm{h}} \mathrm{xI}_{\mathrm{h}}\right)\right) \ldots \ldots . .(7)$

\section{Fungsi Migrasi A ke B}

Dari rumus awal (7) fungsi migrasi antara fase belum terbakar(A) kefase mulaiterbakar(B) adalahjumlah dari perkalian fungsi eksternal (6) dan fungsi internal (7)

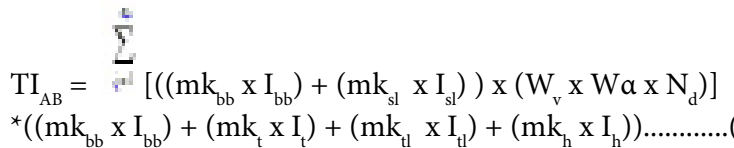

Sehingga dari persamaan (8), model persamaan ini digunakan untuk simulasi untuk mendapatkan initiator dan treshold. Perkalian dua parameter tersebut akan menghasilkan suatu fase kebakaran yang sedang terjadi.

\section{METODE PENELITIAN}

Rangkaian kegiatan untuk menguraikan tentang bahan atau alat penelitian, ,jalan penelitian, dijelaskan di bawah ini. Dalam penyusunan prototipe ini, penulis mengambil wilayah kajian Kutai Barat Kalimantan Timur. Objek penelitian adalah menyusun sebuah prototipe aplikasi interaktif perangkat lunak kebakaran hutan.

\section{Bahan penelitian}

Bahan yang diperlukan dalam penelitian adalah data Citra Landsat 7 ETM untuk mendapatkan informasi konfigurasi vegetasi, data hotspot dari GTZIFFM multitemporal sebagai masukan untuk uji validasi prototipe, peta Topografi skala 1 : 250.000 digunakan untuk mengetahui kontur/ ketinggian yang diturunkan menjadi peta kelerengan, Peta Geologi skala 1 : 250.000 digunakan untuk mengetahui tipe batuan dan penyebarannya di wilayah kajian, peta tanah skala 1 : 250.000, digunakan untuk mengetahui sebaran gambut diwilayah kajian.

\section{Peralatan}

Peralatan utama yang digunakan pada penelitian adalah perangkat lunak, meliputi : Er Mapper 5.5 untuk mengolah dan menginterpretasi secara digital citra, ArcView 3.2 untuk mengolah mengolah data tematik baik grafis maupun atribut yang berformat vector, Able to R2V untuk melakukan proses digitasi pada layar, Microsoft Visual Basic 6 dari Microsoft digunakan sebagai bahasa program untuk penyusunan prototipe aplikasi, DbCAD dari ABACO : digunakan untuk membagi peta-peta tema kedalam satuan-satuan terkecil yang diasumsikan homogen/memiliki karakter yang sama sekaligus sebagai sistem basis data.

\section{Jalan Penelitian}

Penelitian dilakukan melalui tahapan persiapan, kerja lapangan dan pasca kerja lapangan.Tahap persiapan yang dilakukan yakni : Studi kepustakaan, mengumpulkan bahan penelitian, mengolah datadata dan peta-peta sebagai inputan untuk apliksi, merancang dan mengimplementasi-kan prototipe aplikasi perangkat lunak. Kemudian dilanjutkan dengan tahap kerja lapangan yakni: melakukan pengecekan/ uji lapangan terhadap data-data yang diperoleh pada tahap persiapan dan pengamatan objek. Hasil pengujian / pengecekan ulang digunakan sebagai dasar perbaikan dari data-data sebelumnya. Setelah melaksanakan kerja lapangan, tahap selanjutnya adalah melakukan pengolahan ulang data dan peta konfigurasi vegetas, kelerengan, sebaran batubara dan sebaran gambut akhir yang selanjutnya digunakan sebagai masukan untuk prototipe aplikasi. Setelah implementasi prototipe selesai maka dilanjutkan dengan validasi terhadap prototipe aplikasi melalui tahap-tahap berikut ini, yaitu : memasukkan sampel sebaran hotspot dari data GTZIFFM saat $t$ dalam area observasi pada lokasi kajian 
ke dalam aplikasi, melakukan proses running pada aplikasi, membandingkan lokasi sebaran hotpsot pada citra NOAA saat $t+\Delta t$ dengan sebaran hotpsot hasil simulasi aplikasi dan menganalisis, data yang di peroleh dari hasil pengujian sebagai validasi terhadap prototipe dilakukan analisis statistik.

\section{HASIL DAN PEMBAHASAN}

Peracangan perangkat lunak yang dilakukan meliputi perancangan proses, perancangan struktur data dan perancangan antar muka.

Perancangan proses pembuatan aplikasi modelinteraktif ini direpresentasikan melalui Data Flow Diagram (DFD) atau Diagram Alir Data (DAD).

Pada Gambar. 3 ditampilkan DFD level 0, menggambarkan diagram umum perangkat lunak mulai dari input, proses dan output. Input dari aplikasi ini adalah titik-titik panas (hotspot), koordinat batas pengamatan (observation area) dan faktor eksternal penyebab kebakaran hutan berupa faktorfaktor alam (kecepatan angin, arah angin, temperatur dan kelembaban udara). Kemudian algoritma dan perhitungan matematis, meng-hasilkan output berupa simulasi grafis kebakaran hutan, waktu yang diperlukan untuk habis terbakar, serta luas area yang terbakar. (Gambar 4).

Prototipe aplikasi ini terdiri dari 5 proses utama yang dijalankan secara berurutan. Kelima proses tersebut adalah input faktor alam, set observation area, add hotspot, proses simulasi dan proses reporting, dimana masing-masing akan dibahas lebih lanjut di bawah ini.

Input faktor alam yang dimaksud terdiri dari kecepatan angin, arah angin, suhu dan kelembaban udara. Nilai-nilai inilah yang menjadi faktor afektifitas (pengaruh) eksternal terhadap ekskalasi kebakaran hutan. (Gambar. 5).

Proses pembobotan dilakukan dengan mengalikan indeks intesitas dan besarnya magnitude korelatif setiap faktor alam.

DFD proses Set Observation Area, ditunjukan pada Gambar 6, yangmana dilakukan proses input koordinat batas. Yang dimaksud batas adalah koordinat awal dan akhir dari sebuah area berbentuk persegi panjang, yang digunakan untuk membatasi area pengamatan pada saat simulasi dijalankan. Didalam area inilah titik-titik hotspot akan dimasukkan.

Proses add hotspot, sebagaimana terdapat pada Gambar. 7 adalah proses inisialisasi hotspot sebagai Fire Pixel yang mempunyai bobot dan warna, dimana bobot menentukan lamanya waktu ekskalasi kebakaran dan warna melambangkan perubahan-perubahan state pada fase kebakaran.

Proses simulasi merupakan inti dari aplikasi ini, yaitu berupa pemodelan grafis/ spasial kebakaran hutan. Proses ini diawali dengan menginisialisasi fire pixel tetangga untuk mendapatkan koordinat tetangga yang direpresentasikan dengan matriks. Setelah koordinat tetangga didapatkan kemudian dilakukan pembobotan FP, yaitu dengan menghitung pengaruh faktor eksternal dan internal FP. Faktor internal adalah besarnya afektifitas FP tersebut pada layer sebaran gambut, formasi batuan (sebaran dan sisipan batubara), kemiringan lahan dan layer konfigurasi vegetasi. (Gambar.8)

Dengan pembobotan ini akhirnya sebuah FP dapat ditentukan tingkat ekskalasi kebakarannya, yang akhirnya berpengaruh pada perubahan keadaan (state) pada tiap-tiap fase kebakaran. Looping proses ini terjadi terus sampai pada batas Observation Area atau jika user menghendaki untuk menghentikan simulasi.

Proses akhir dari aplikasi ini adalah dihasilkannya report berupa pemodelan grafis akhir dari suatu proses kebakaran hutan. (Gambar. 9).

Dari pemodelan grafis inilah didapatkan waktu simulasi yang kemudian dikonversi dengan konstanta tertentu sehingga menghasilkan besaran waktu, yang mengambarkan lamanya suatu area terbakar habis di dunia nyata. Selain itu jumlah FP dengan keadaan padam (warna hitam) yang terlihat pada pemodelan grafis dapat digunakan untuk menghitung luas area yang terbakar pada waktu simulasi tertentu.

Pada aplikasi ini dibutuhkan data-data peta yang terdiri dari 4 layer yaitu layer sebaran gambut, formasi batuan, kemiringan lahan dan layer konfigurasi vegetasi, dimana tiap-tiap layer memiliki tabel data tersendiri yang menjelaskan atribut dari entitasentitas yang termuat dalam peta-peta tersebut. Selain 4 tabel diatas, dibutuhkan satu buah tabel untuk menampung penambahan entitas baru, berupa hot spot yang bersifat temporal, yaitu pada saat satu eksekusi simulasi dijalankan. Dalam DbCADdev, software yang digunakan untuk pembuatan aplikasi kebakaran hutan ini, mempunyai struktur basisdata standar dalam dBaseIII File (.dbf), sehingga untuk keempat tabel diatas, memiliki struktur yang sama.

Perancangan antarmuka dalam penelitian ini adalah antarmuka yang nantinya digunakan oleh pengguna (user) aplikasi kebakaran hutan ini. Peneliti membagi menjadi 2 kategori, berupa disain antarmuka secara umum dan disain antarmuka fungsi utama.

Disain antarmuka secara umum pada Gambar. 10, menggambarkan seluruh fungsi atau fasilitas yang dimiliki oleh aplikasi kebakaran hutan. Menu utama terdiri dari item-item yang akan dijelaskan melalui Gambar 11.

Secara umum struktur data dalam aplikasi ini cukup sederhana, dimana koordinat Fire Pixel (FP) diimplementasikan dalam array 2 dimensi, dengan batasan 10 titik panas (hot spot) sebagai input. Sedangkan untuk peletakan titik panas sebagai Fire Pixel diperlukan variabel tambahan berupa XCenter dan YCenter. Untuk menghentikan simulasi, digunakan dua buah kontrol, yaitu melalui input jarak radius kebakaran hutan dari titik panas (hot spot) dan kontrol langsung dari user melalui penekanan tombol 
STOP. Untuk itu digunakan variabel global control dengan type Boolen. Sedangkan untuk menyimpan koordinat batas area yang akan diobservasi, digunakan variabel yang bersifat Private, yaitu $(\mathrm{X} 1, \mathrm{Y} 1)$ untuk koordinat ujung atas persegi panjang dan (X2,Y2) untuk menyimpan koordinat ujung bawah persegi panjang. Variabel-variabel waktu digunakan untuk mengimplementasikan fungsi pengaturan waktu yang nanti akan dijelaskan lebih lanjut. Variabel magnitude korelatif digunakan untuk menyimpan kadar afektifitas atau pengaruh faktor-faktor yang mempengaruhi proses cepat / lambatnya kebakaran hutan. Dalam hal ini, tingkat afektifitas dibedakan berdasarkan jenis faktor yang mempengaruhinya, yaitu faktor eksternal dan internal. Sedangkan untuk pembobotan tiaptiap magnitude korelatif tersebut diimplementasikan berdasarkan pende-katan fisis dalam realita kebakaran hutan. Untuk menentukan nilai indeks tiap piksel yang akan divisualisasikan berdasarkan jenis layer masingmasing, diperlukan variabel penyimpanan indeks intesitas.

Variabel-variabel ini akan menyimpan nilai dari pemanggilan fungsi GetIn_Faktor_Eksternal dan GetIn_Faktor_Internal. Untuk menghitung jumlah state yang memasuki terbakar dan padam digunakan dua variabel yaitu stateterbakar dan statepadam. Dengan demikian pada output simulasi dapat diketahui jumlah pixel yang terbakar dan yang padam, sehingga bisa digunakan untuk menghitung luas area yang terbakar penuh.

Dalam proses pembuatan dan pengolahan basisdata aplikasi ini, DBCADdev menyediakan beberapa fungsi yang dipakai penulis untuk membuat prototipe aplikasi modelinteraktif kebakaran hutan ini.

1.Proses Open Database Area: DbCADdev menghandle tabel-tabel (Graphic Database dan File Index nya) dalam area yang berbeda-beda.

2.Proses Menampilkan Basisdata pada Graphic Window : hampir di setiap script yang mengakses basisdata, selalu diakhiri dengan script ini. Dengan demikian kita akan melihat hasil up-date basisdata.

3.Proses Konversi Struktur Basisdata dari format ShapeFiles (.SHP) : untuk mengkonversi struktur basisdata yang dibuat dari ShapeFile (.SHP) ke dalam struktur basisdata standar DBCADdev, diperlukan terlebih dahulu proses Open Area Database, kemudian baru dilakukan proses konversi. Proses konversi ini akan menambah satu buah field bernama "EXTLINK" pada struktur standar basisdata DBCADdev. Proses ini dilakukan di luar pembuatan aplikasi.

4.Proses Create Database: proses ini untuk menciptakan basisdata baru tanpa harus mengkonversi dari formasi file yang lain.

5.Proses Access Database: untuk mengakses basisdata harus terlebih dahulu dilakukan perintah Open database Area.

\section{Proses Searching}

Database : untuk melakukan proses Searching Database, terlebih dahulu dilakukan perintah pengaksesan yang akan dijadikan objek pencarian data. Namun demikian dalam implementasinya seringkali didahului dengan script devsetaperture ([aperture diameter), dimana script ini digunakan untuk men-set diameter dari area pencarian yang berarti akan mampu mendeteksi semua entitas sejauh diameter yang diinginkan dari salah satu piksel.

Untuk mengimplementasikan proses-proses yang ada dalam aplikasi kebakaran hutan ini, peneliti membuatnya kedalam fungsi-fungsi program yaitu fungsi GetIn_Faktor_Eksternal, fungsi GetIn_ Faktor_Internal, fungsi Pengaturan_Waktu, Fungsi Transformasi dan fungsi Pembobotan_FP.

Fungsi untuk mengolah nilai faktor eksternal pada dasarnya memiliki algoritma yang sama. Perbedaannya hanyalah nilai dan kondisi untuk tiap-tiap faktor. Secara umum , fungsi GetIn_Arah_Angin, GetIn_ Kelembaban, GetIn_Suhu dan GetIn_Jarak_Tetangga memiliki kesamaan format penulisan script. Yang dimaksud dengan GetIn_Jarak_Tetangga adalah fungsi untuk melakukan pembobotan pada piksel yang sedang diinisialisasi berdasarkan jarak piksel tersebut degan titik hotspot. Semakin jauh dari titik hotspot, semakin besar nilai GetIn_Jarak_Tetangga, yang berarti semakin keil tingkat afektifitas (pengaruh) kebakaran hutannya.

Fungsi GetIn_Faktor Internal untuk tiap-tiap layer juga memiliki kesamaan algoritma dan format penulisan program. Perbedaannya hanyalah alamat dan

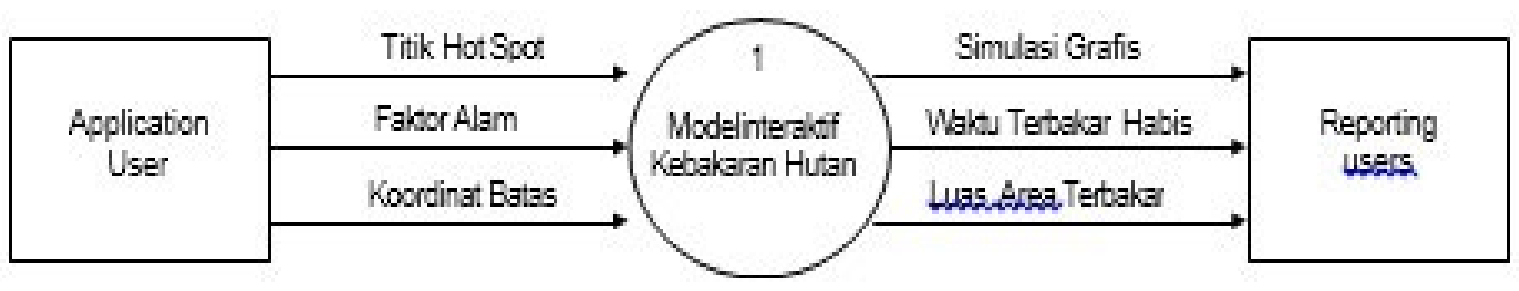

Gambar 3. DFD level 0 
area basisdata yang dituju, serta besarnya bobot untuk tiap-tiap klasifikasi layer. Tiap-tiap fungsi diawali dengan membuka area database, kemudian searching koordinat piksel, dan dilanjutkan dengan pembobotan piksel. Ada empat buah fungsi GetIn_Faktor_Internal yang diimplementasikan dalam aplikasi ini, yaitu GetIn_Konfigurasi_Vegetasi, GetIn_Formasi_Batuan, GetIn_Sebaran_Gambut dan GetIn_Kemiringan_ Lahan.
Fungsi pengaturan dimaksudkan untukmenghitung lamanya proses simulasi mulai dari diaktifkannya tombol START sampai ditekannya tombol STOP pada MainFrom simulasi. Waktu simulasi didapatkan dengan mengurangi waktu akhir dikurangi waktu awal simulasi.

Fungsi transfomasi merupakan fungsi utama untuk meng-generate Fire Pixel (FP). Untuk menjalankan fungsi ini dibutuhkan dua buah parameter bertipe

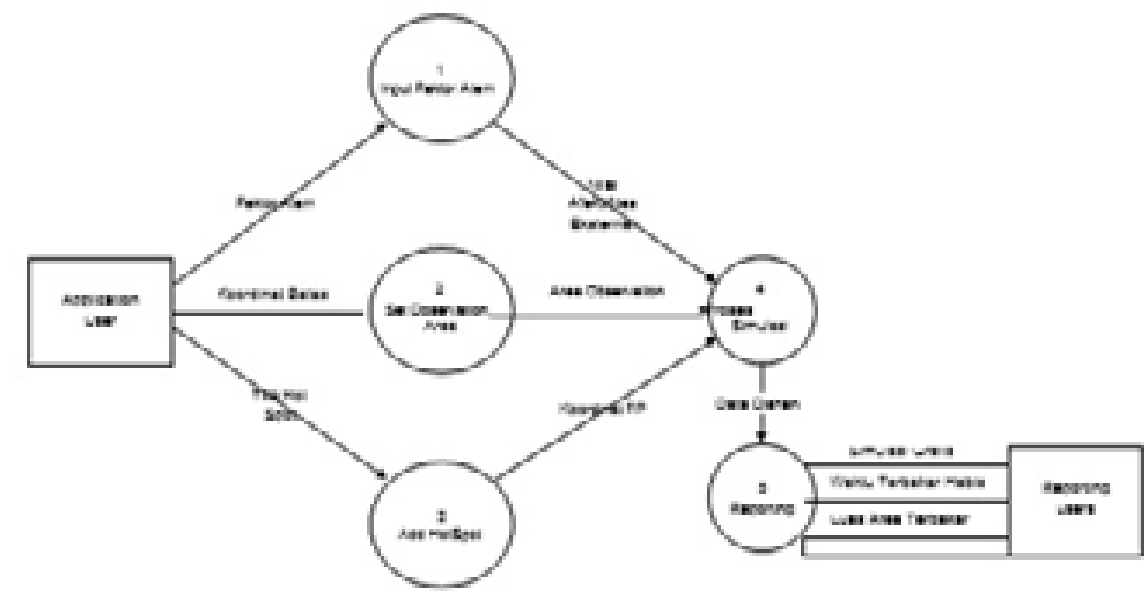

Gambar 4. DFD level 1
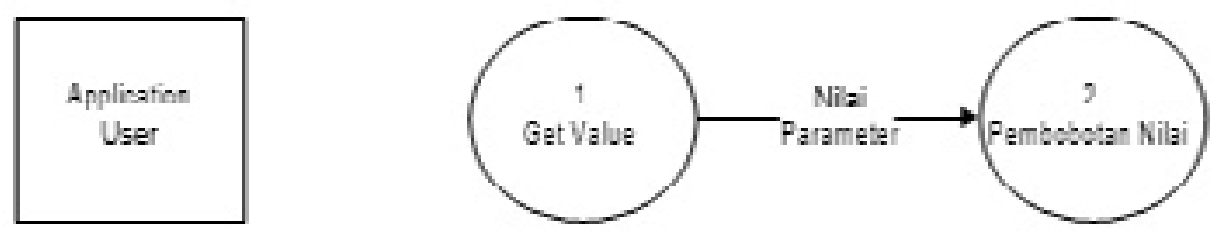

Gambar 5. DFD Level Proses Input Faktor Alam

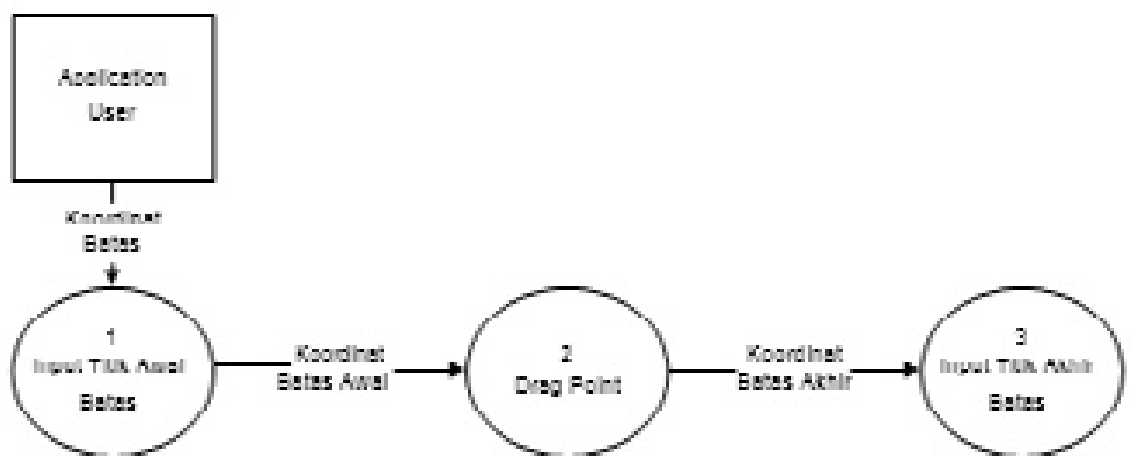

Gambar 6. DFD Level 2 Proses Set Observation Area 


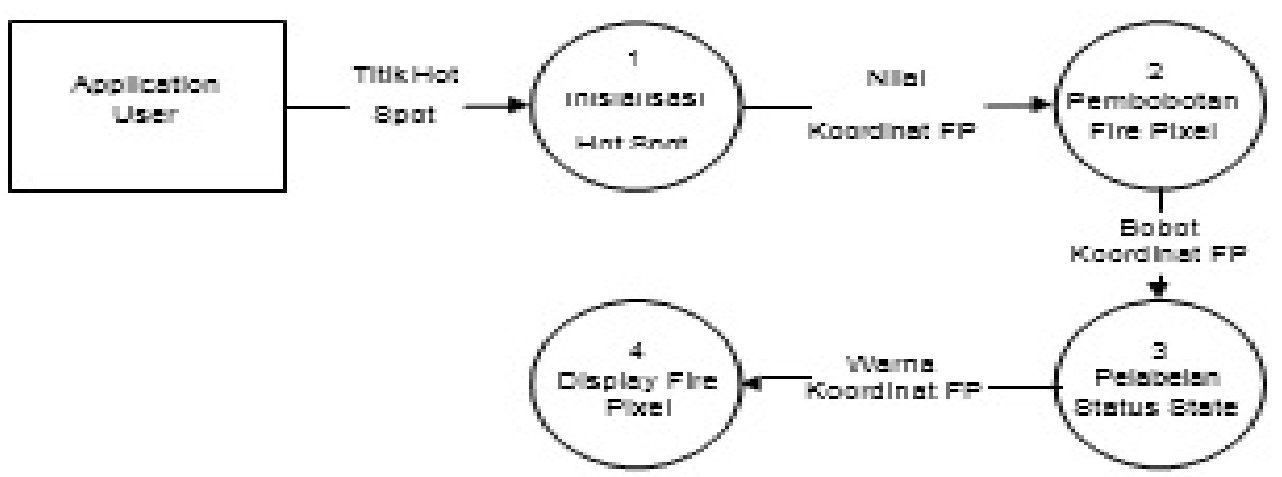

\section{Gambar 7. DFD Level 2 Proses Add Hot Spot \\ Proses Simulasi}

double, yaitu nilai $\mathrm{x}$ dan $\mathrm{y}$ dari pixel yang sedang diinisialisasi.

Yang dimaksud dengan pembobotan Fire Pixel (FP) adalah menghitung nilai afektifitas (pengaruh) faktor-faktor) pemicu kebakaran hutan.

Pembuatan antarmuka (interface) dalam aplikasi ini tidak jauh dari proses perancangan. Berikut ini implementasi dari perancangan antarmuka form-form utama dalam aplikasi ini.

\section{Antarmuka FormLogin}

Form ini berfungsi sebagai security apikasi, yang berarti dilakukan pembatasan hak pakai user.

\section{Antarmuka MDIForm}

MDIForm merupakan gambaran skema dari fungsifungsi atau fasilitas yang dimiliki aplikasi.

\section{Antarmuka MainForm}

Inti dari Aplikasi Model Interaktif ini terletak pada MainForm, dimana pada form ini tempat dilakukannya input data, eksekusi datasimulasi kebakaran hutan, serta terdapat fasilitas membuka report.

\section{Antarmuka MapViewer}

Form MapViewer dimaksudkan untuk melihat peta secara lebih terperinci untuk masing-masing layer. Jika user menghendaki format lain, pada aplikasi ini juga tersedia fasilitas untuk membuka peta dan basisdatanya dalam aplikasi Arc_View (Pada MDIForm, click View Data lalu pilih Arc_View).

\section{Antarmuka ReportForm}

Output dari aplikasi ini ditampilkan melalui Reportform, yaitu berupa hasil simulasi grafis kebakaran hutan, luas area terbakar penuh dan waktu simulasi yang diperlukan untuk membakar habis suatu area. Di form tersebut juga ada fasilitas untuk mencetak report hasil simulasi.

Metode uji coba yang digunakan untuk mengukur tingkat validasi dari aplikasi ini adalah uji Kolmogorov-
Smirnov Dua Sampel. Uji ini digunakan untuk menguji hipotesis komparatif sampel independen bila datanya berbentuk ordinal yang telah tersusun pada tabel distribusi frekuensi kumulatif dengan menggunakan kelas-kelas interval. Rumus yang digunakan adalah persamaan berikut:

$\mathrm{D}=\operatorname{maksimum}\left[\mathrm{Sn}_{1}(\mathrm{x})-\mathrm{Sn}_{2}(\mathrm{x})\right]$

Pengukuran melalui metode ini dapat diterima kebenarannya bila nilai KD hitung lebih kecil atau sama dengan $\mathrm{KD}$ tabel. Untuk menghitung nilai $\mathrm{KD}$ digunakan persamaan 13, Yang dimaksud KD hitung adalah hasil perhitungan KD dengan menggunakan data-data hasil simulasi, sedangkan KD tabel dihitung dengan berdasarkan data-data lapangan.

$$
\underset{\text { Skenario 1 }}{K_{D}=1, \mathfrak{B}} \sqrt{\frac{n_{1}-n_{2}}{n_{1} n_{2}}}
$$

Pada uji skenario ini, masukan aplikasi berupa titik-titik hotspot diukur berdasarkan data peta hotspot dan peta koordinat wilayah Kutai Barat dari GTZ-IFFM bersumber dari satelit NOAA 16 tanggal 7 Juni 2004 dan 26 Juni 2004 (peta yang dimaksud terdapat dalam lampiran). Faktor alam yang menyertai pada waktu tersebut adalah sebagai berikut :

1.Tanggal 7 Juni 2004 (kecepatan angin : 8,33 m/ dtk, arah angin : 45o, temperatur udara rata-rata : $290 \mathrm{o}$, kelembaban rata-rata : $7 \%$ )

2.Tanggal 26 Juni 2004 (kecepatan angin : 8,33 m/ dtk, arah angin: 1850 , temperatur udara rata-rat: $290 \mathrm{C}$, kelembaban rata-rata: $73 \%$ )

Data pada tanggal 7 Juni 2004 merupakan masukan aplikasi, sedangkan data pada tanggal 26 Juni 2004 digunakan sebagai data riil (X1,Y1) yang digunakan sebagai pembanding luaran simulasi (X2,Y2).Waktu simulasi yang diperlukan untuk radius 4 piksel dari hotspot masukan adalah 115 detik. Hasil pengukuran 


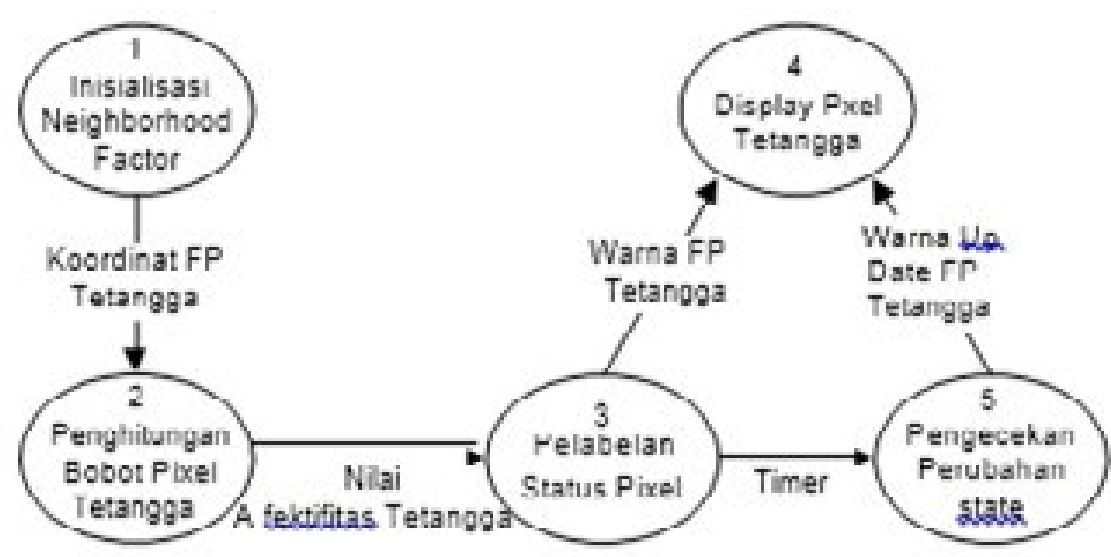

Gambar 8. DFD Level 2 Proses Simulasi

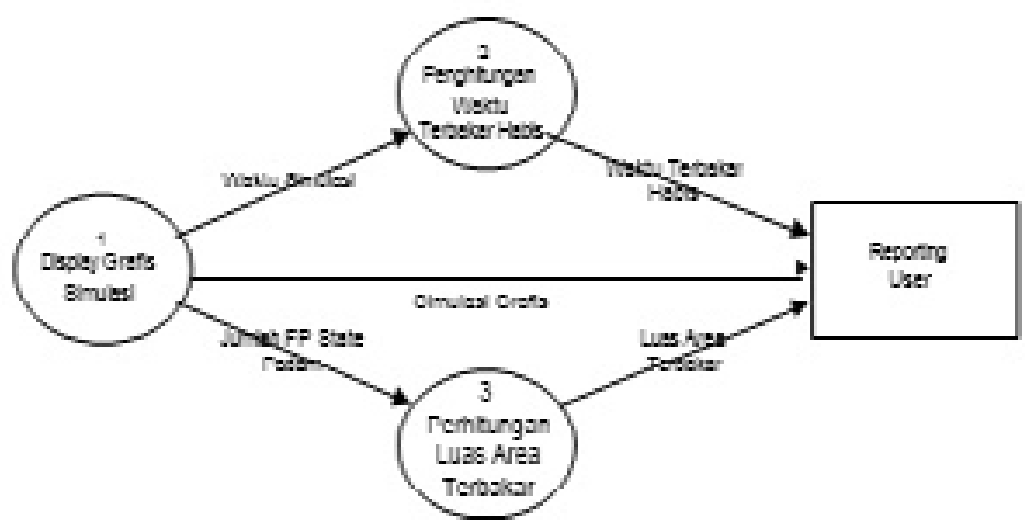

Gambar 9. DFD Level 2 Proses Reporting

skenario 1 diperoleh dengan nilai $\mathrm{KD}$ hitung = 1,5722 dan nilai KD tabel $=1,9176$. Pengukuran ini menandakan tingkat validasi kebenaran aplikasi dapat diterima, karena nilai KD hitung $<$ KD tabel.

Skenario 2

Pada uji skenario 2 ini, masukan aplikasi berupa titik-titik hotspot diukur berdasarkan data peta hotspot dan peta koordinat wilayah Kutai Barat dari GTZ-IFFM bersumber dari satelit NOAA 16 tanggal 6 April 2004 dan 26 April 2004 (peta yang dimaksud terdapat dalam lampiran). Faktor alam yang menyertai pada waktu tersebut adalah sebagai berikut :

1.Tanggal 6 April 2004 (kecepatan angin : 8,33 m/ dtk, arah angin : $135 \mathrm{o}$, temperatur udara rata-rata : $29 \mathrm{oC}$, kelembaban rata-rata : $73 \%$ )

2.Tanggal 26 April 2004 (kecepatan angin : 8,33 m/ dtk, arah angin : $210 \mathrm{o}$, temperatur udara rata-rata : $29 \mathrm{oC}$, kelembaban rata-rata : $73 \%$ )

Data pada tanggal 6 April 2004 merupakan masukan aplikasi, sedangkan data pada tanggal 26 April 2004 digunakan sebagai data riil (X1,Y1) yang digunakan sebagai pembanding luaran simulasi (X2,Y2). Waktu simulasi yang diperlukan untuk radius 4 piksel dari hotspot masukan adalah 120 detik. Hasil pengukuran skenario 2 diperoleh dengan nilai $\mathrm{KD}$ hitung $=1,36$ dan nilai $\mathrm{KD}$ tabel $=1,5722$. Pengukuran ini menandakan tingkat validasi kebenaran aplikasi dapat diterima, karena nilai KD hitung $<$ KD tabel. Dari uji coba yang telah dilakukan diatas terbukti bahwa aplikasi cukup layak digunakan untuk mensimulasikan proses penjalaran api bila terjadi kebakaran hutan.

\section{KESIMPULAN}

Setelah dilakukan pembuatan aplikasi yang disertai dengan tahap uji coba program, dapat diperoleh kesimpulan bahwa telah berhasil disusun suatu aplikasi perangkat lunak simulasi kebakaran hutan ini, yang dapat dioperasikan secara interaktif dengan cakupan didefinisikan suatu satuan perluasan eskalasi kebakaran atau FirePixel yang mewakili granularitas data riil lapangan sebesar 400X400 m dan kondisi pada sebuah satuan perluasan eskalasi kebakaran atau Fire Pixel diasumsikan homogen. Letak (posisi geografis) area pengamatan (set observation) dan lokasi hot spot dapat dikustomisasi (disetting) oleh pengguna secara interaktif.Kecepatan dan arah angin, temperatur rata-rata, kelembaban rata-rata dari simulasi dapat dikustomisasi secara interaktif pada saat simulasi. 
Report aplikasi berupa: pola sebaran kebakaran secara grafis, luasan kebakaran, waktu simulasi kebakaran. Proses inisialisasi fire pixel berjalan secara serial untuk lebih dari satu titik hot spot dalam sekali simulasi di area observasi yang dikehendaki pengguna.Proses perubahan state antar fase kebakaran dipengaruhi oleh faktor pembobotan piksel dan faktor peluruhan energi. Fungsi timer untuk mengkonversi waktu simulasi ke dalam waktu riil untuk membakar habis suatu area belum dapat dimunculkan, hal ini disebabkan belum ditemukannya perhitungan konstanta untuk mengkonversikan waktu simulasi.

\section{UCAPAN TERIMA KASIH}

Tidak lupa penulis ucapkan terima kasih kepada para pembimbing atas bimbingan, dorongan semangat sehingga mampu memperluas wawasan penulis sehingga mampu menyelesaikan penelitian ini.

\section{DAFTAR PUSTAKA}

Abaco, (1999). User guide DbCADdev, Abaco. Cormen, (1992). Introduction to Algorithms, The MIT Press., Massachuset.

Finney, Mark A., 1998, “FARSITE : Fire Area SimulatorModel Development and Evaluation”, US Forest Service, diperoleh 20 Janurai 2015.

Jones, D.W, (1999). Simulation Pending Evenst Set Algorithm. University of Iowa Department of Computer Science.

Jensen, J.R., (1996).Introductory Digital Image Processing, a Remote Sensing Prespective", second edition, Prentice Hall, NJ 07458.

Kusumawardhani. A., Cordova H, Widodo A.M., (2000).The Prototype Development of Forest Fire Danger Rating System Information (FDRS)", Joint Project of ITS and BPP Technology (No:11/SPK/ PPTISDA/BPPT/IX/1999-2000).

Kusumawardhani., Cordova H., Widodo A.M. , (2000).The Modeling Of Forest and Land Fire Rating Danger Based On Remote Sensing Data and Geographic Information Systems (A Case Study The Pontianak Surrounding) ", Domestic Collaborative Research Grant (DCRG).

Law A. M., Kelton. D, (1999). Simulation Modelling \& Analysis, Mc Graw hill, Inc, New York.

National Wilfire Coordinating Group., April (2006). National Wildfire Coordinating Group Fireline Handbook, appendix B : Fire Behaviour, diperoleh 11 September 2015.

Oakley C.O, (1957) "Analytic Geometry", Barnes and Nobles Books, USA.

Prasasti I., Parwati E., (1995). Proceedings Peretemuan Ilmiah Tahunan ke 5 Masyarakat Penginderaan Jauh (MAPIN), Institut Teknologi Sepuluh Nopember.

Rakor SIGNas VI, (2001). Panduan Pengembangan Sistem Informasi Geografis, Rakor SIGNas VI, Bandung.
Reeves W.T, (1985). Approximate and Probalistic algoritm for shading and Rendering Structured Particle System", Computer Graphic, vol. 19, no. 3, pp 313-332.

Swain, P., (1978). Remote Sensing The Quantitative Approach", Mc Graw Hill, Inc.

http://www.vadscorner.com/haze.html, diperoleh 18 Juni 2015.

http://www.iffm.org/Indonesia/index.html, diperoleh18 Juni 2015.

http://www.iffm.org/hsmap.html, diperoleh 18 Juni 2015. 